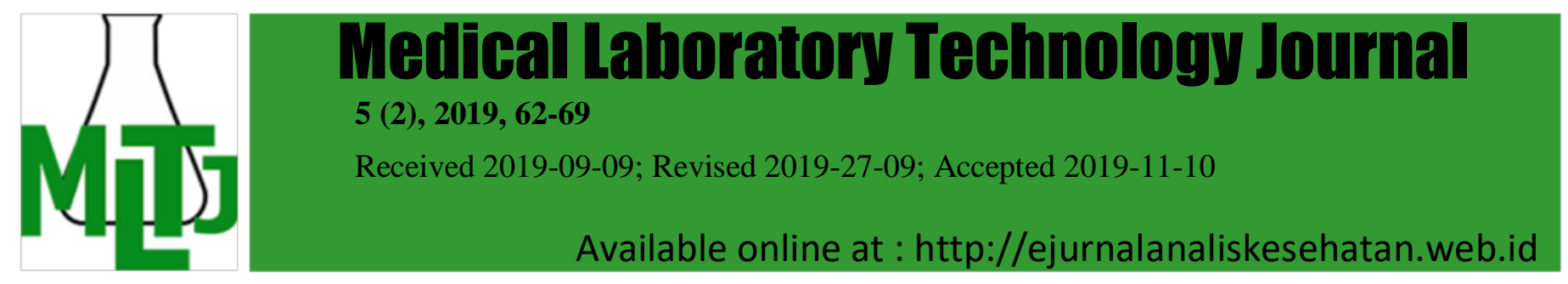

\title{
Acute Toxicity Test of Black Pomegranate Peel Extract (Granati Fructus Cortex) Against Larvae of Shrimp (Artemia salina Leach)
}

\author{
*Rofiatu Sholihah, Lingga Aditya, Nosa Ika Cahyariza
}

Immunology Study, Postgraduate Faculty, Universitas Airlangga Campus B Jl. Airlangga No.4 - 6, Airlangga, Gubeng, Surabaya, East Java Indonesia 60115. Email : roviash12@gmail.com DOI: 10.31964/mltj.v\%vi\%i.242

\begin{abstract}
Toxicity test on red pomegranate has done, while in black pomegranate is not widely known. Black pomegranate peel (Granati Fructus Cortex) has some chemical ingredients such as saponins, flavonoids, tannins, and alkaloids. Alkaloids, saponins, and flavonoids are thought to be toxic at certain levels. This study aimed to determine the effects of toxic black pomegranate peel extract (Granati Fructus Cortex) against larvae of shrimp (Artemia salina Leach) indicated LC50 values below $1000 \mu \mathrm{g} / \mathrm{ml}$. This study is purely experimental by using Brine Shrimp Lethality Test (BSLT). The experiments divided into five groups, namely ethanol extract of black pomegranate peel (Granati Fructus Cortex) with a concentration of 100, 150, 200, $250 \mathrm{ppm}$, and negative control (seawater). Mortality data percentage of Artemia salina Leach analyzed by probit analysis. Results showed that the extract of black pomegranate peel (Granati Fructus Cortex) has a toxic effect on larvae of Artemia salina Leach with LC50 values of $114.090 \mu \mathrm{g} / \mathrm{ml}$. From these results, it can conclude that black pomegranate peel extract has a potential acute toxic to larval shrimp (Artemia salina Leach) with Brine Shrimp Lethality Test (BSLT) method.
\end{abstract}

Keyword: pomegranate black peel; acute toxicity test; brine shrimp lethality test; Artemia salina Leach.

\section{INTRODUCTION}

Indonesia is a rich country in flora and fauna, which widely spread in various regions; these natural resources have utilized by the population, which is more than 230 million people. This diversity has a significant impact on the development of biotechnology in the use of biodiversity by the community, one of which is the use of natural medicines or traditional medicines (Fitri, Oktiarni, \& Arso, 2018). In developing of the health sector, conventional medication needs to be developed and gradually utilized based on a scientific foundation, so that it can be used in the issue of standard health services to the community (Roihatul, 2014).

There are various kinds of traditional medicines derived from plants and have studied in much chemical content and efficacy in them. But there are still many plants whose toxicity levels are not yet known, so it needs to be further investigated to determine safety ingredient (Abnaz, Zahra Dzakirah \& Jutti Levita, 2018). One of the natural ingredients that can utilize is black pomegranate skin (Granati Fructus Cortex). There are several types of pomegranate, namely white pomegranate, red pomegranate, and black pomegranate (Setiawati, 2014). Black pomegranate skin (Granati Fructus Cortex) has several chemical contents such as saponins, polyphenols, flavonoids, tannins, and alkaloids (Rizka \& Saptarini, 2018). Flavonoids, polyphenols, tannins, and alkaloids have benefits as an anti-microbial

Corresponding Author: Rofiatu Sholihah

Immunology Study, Postgraduate Faculty, Universitas Airlangga Campus B Jl. Airlangga

No.4 - 6, Airlangga, Gubeng,Surabaya, EastJavaoIndonesia, 60115.

Email:roviash12@gmail.com 
and antioxidant. Alkaloid compounds, saponins, and flavonoids are assumed to be toxic at certain levels (Khotimah, 2016).

Toxicity tests are needed to assess the safety of the drug, or ingredients used as supplements or food (Makiyah \& Tresnayanti, 2017). It is also to protect the community from potentially harmful effects. The effects of drug toxic are often seen in the liver because the liver plays a central role in the metabolism and extraneous materials that enter the body. The liver will change the structure of lipophilic to the hydrophilic drug, so it quickly removed from the body through urine or gallbladder (Syam, 2016). Excretion via gallbladder allows xenobiotics buildup in the liver to cause hepatotoxicity effects (Putri, 2016).

One of the methods used to test the toxicity is to use the larva of the shrimp type Artemia salina Leach. In this method, A. Salina Leach used as A bioindicator. This method is easy to work with, cheap, short time detection, and accountable (Sangi, Momuat, \& Kumaunang, 2012). The toxicity test in red pomegranate has been done much, while the black pomegranate is not widely known. So, based on this background, the author is interested in doing a black pomegranate toxicity test on shrimp larva (Artemia salina Leach).

This study aims to determine the toxic effects of black pomegranate peel extract (Granati Fructus Cortex) on shrimp larvae (Artemia salina Leach) and to determine LC 50 value of shrimp larvae (Artemia salina Leach) after supplying of black pomegranate peel extract (Granati Fructus Cortex).

\section{MATERIALS AND METHOD}

The research conducted at Animal Laboratory of Institue of Health Science Bhakti Wiyata Kediri. The ingredients used are black pomegranate peel extract, ethanol, distilled water, concentrated $\mathrm{HCl}, \mathrm{HCl} 2 \mathrm{~N}$, Mayer, Wagner, Dragendorff, hexane, metal Mg, FeCl3 1\%, acetic acid, concentrated sulfuric acid, Artemia salina Leach larvae, yeast as shrimp larvae feed and seawater. The tools used in this research are Philips blender HR 2116, triple beam balance MB-2610, Rotavapor R100 Rotary Evaporator, Waterbath health type YNC-WBE-8L. Blender used to crush and smoothing black pomegranate skin, analytical scales for weighing black pomegranate skin that has become into powder. Rotary Evaporator is a powder stirrer black pomegranate that has macerated with ethanol $70 \%$ to obtained concentrated extracts. The function of the water bath is to remove ethanol from the black pomegranate powder.

\section{Extraction}

Black pomegranate peel used previously weighed, then dried and blended with a blender. Pomegranate peel powder as many as 100 grams put into Erlenmeyer $1000 \mathrm{~mL}$; then, the dust was macerated with $70 \%$ ethanol repeatedly then concentrated with a rotary evaporator until crude extract obtained. Make an extract concentration solution of 500 ppm by dissolving $50 \mathrm{mg}$ of extract sample dissolved with $100 \mathrm{~mL}$ of seawater. From 500 ppm solution, then make a solution with concentrations of $250,200,150$, and 100 ppm by dilution. For control (0 ppm) is done without the addition of extracts (Rakhmawati, Qadriyati, \& Wijayanti, 2011).

\section{Phytochemical Test}

The ethanol extract is further obtained by phytochemical testing to determine the content of its compounds. Tests conducted include flavonoids, saponins, tannins, alkaloids, and analysis, not ethanol (Simaremartye, 2014). 


\section{Selection of Artemia salina Leach eggs}

The selection of shrimp eggs made by soaking the eggs in distilled water for one hour. Good eggs will settle while bad eggs will float (Filha Ferraz, Lombardi, Guzzo, \& Guimarães, 2012).

\section{Preparation of larvae Artemia salina Leach}

Shrimp larvae are prepared by incubating Artemia salina Leach eggs for two days before testing. The hatching does by soaking the shrimp eggs into an aquarium container filled with seawater and given aeration. After 48 hours of soaking, the eggs hatch and produce larvae of Artemia salina Leach which are ready for use in a testing (Filha Ferraz et al., 2012).

\section{Toxicity Test}

Test solutions with concentrations of $250,200,150$, and 100 ppm, each in a pipette of $10 \mathrm{~mL}$, were inserted into a vial bottle, and ten tail shrimp larvae aged two days added. The observation was carried out for 24 hours on shrimp larvae death, where each concentration was carried out twice during repetition and compared with control. Consideration of the number of dead larvae counted within 6 hours, namely the 6th, 12th, 18th, and 24th hours. Shrimp larvae disclosed to be dead while they are motionless for 10 seconds. After observation for 24 hours later, the level of toxicity determined by calculating the number the dead larvae. LC50 value specified with a linear regression analysis in table 1 (Rampe \& Toumbuku, 2015).

Table 1. Level of Toxicity Value LC50

\begin{tabular}{lcc}
\hline No. & LC50 Value $(\mu \mathrm{g} / \mathrm{ml})$ & Toxicity Levels \\
\hline 1. & $0-250$ & Very toxic \\
2. & $250-500$ & Toxic \\
3. & $500-1000$ & Intermediate \\
4. & $>1000$ & Non toxic \\
\hline
\end{tabular}

Research data will be processed and presented in tabular form. LC50 calculation data analysis do by data \% mortality transformed into a concentration log. Toxicity test data will be analyzed by Probit Analysis using SPSS 16.0 for windows to find out LC50 price.

\section{RESULTS AND DISCUSSION \\ Yield Extract}

Based on the examination results of black pomegranate peel extraction results are presented in Table 2 .

Table 2. Results of Black Pomegranate Simplisa Powder Extraction Results (Granati Fructus Cortex).

\begin{tabular}{cccc}
\hline $\begin{array}{c}\text { Simplisa Powder } \\
\text { Weight }(\mathrm{g})\end{array}$ & Solvent & Extract Weight $(\mathrm{g})$ & $\begin{array}{c}\text { Yield Percentage } \\
(\% \mathrm{~b} / \mathrm{b})\end{array}$ \\
\hline 100,0 & Etanol $70 \%$ & 20,676 & 20,676 \\
\hline
\end{tabular}

Table 1 shows the results of black pomegranate peel powder extraction (Granati Fructus Cortex). The removal produces a yield of $20,676 \%$ black pomegranate peel extraction. The concentrated extract tested free of ethanol, so it 
did not affect the treatment of experimental animals, in other words, the cause of death of Artemia salina Leach larvae was not due to ethanol but due to the active compound contained in the extract. Ethanol-free test results presented in table 3.

\section{Table 3. Results of Ethanol Free Test for Black Pomegranate Peel Extract (Granati} Fructus Cortex)

\begin{tabular}{ccc}
\hline Ethanol Free Test & $(+)$ Literatur Results & Testing Resultd \\
\hline /Extract $+\mathrm{H}_{2} \mathrm{SO}_{4}$ & There is no specific eter & No specific eter smell \\
concentrated + & smell & \\
$\mathrm{CH}_{3} \mathrm{COOH}$ heated & & \\
\hline
\end{tabular}

\section{Phytochemical Test}

Phytochemical results test observations of black pomegranate (Granati Fructus Cortex) extract can be seen in table 4.

Table 4. Phytochemical Test Results of Black Pomegranate Peel Extract (Granati Fructus Cortex)

\begin{tabular}{clc}
\hline Chemical Content & \multicolumn{1}{c}{ Testing Results } & Description \\
\hline Flavonoid & Orange reddish forming & + \\
Saponin & Foam forming & + \\
Tanin & Blackish blue colour forming & + \\
Alkaloid & No sediment forming & - \\
\hline
\end{tabular}

The results of the test positive of flavonoids. A reddish-orange color characterizes the positive outcome of the flavonoid test. Liquid flavonoids consist of phenols that commonly found in many vascular plants. Flavonoids show biochemical activities such as antioxidant, anti-viral, anti-bacterial, and anti-cancer. Flavonoids can inhibit the proliferation of cancer cells with a cell cycle inhibitory mechanism and induce apoptosis. Maryati's Research (2006) proves that the flavonoids are isolated from the ethyl acetate fraction of the ethanol extract of Life (Gynura procumbens (Lour.) MERR) has cytotoxic activity with IC50 of $98 \mu \mathrm{g} / \mathrm{mL}$ against breast cancer cells T47D (Rampe \& Toumbuku, 2015).

The next test is the saponin test, saponin test on black pomegranate extract shows positive results, this is due to the formation of a stable foam when black pomegranate extract is added to water and heated, then cooled and shaken to form foam. Extracts and water heated to increase the solubility of saponins in water. The formation of foam caused by glycosides contained in black pomegranate peel extract so froth formed in water and will hydrolyze into glucose and other compounds (Muthmainnah, 2017). Saponin is a compound in the form of glycosides that are widespread in high-level plants as well as some marine animals and are a diverse group of compounds in the structure, physicochemical properties, and biologic effects (Yanuartono, Purnamaningsih, Nururrozi, \& Indarjulianto, 2017). Saponins are hypocholesterolemic, Immunostimulatory, and Anticarcinogenic. Anticarcinogenic mechanisms of saponins include direct antioxidant and cytotoxic effects on cancer cells (Permana, Husni, \& Budhiyanti, 2016).

The tannin test on black pomegranate peel extract also showed positive results. Tannin is a phenolic compound that is water-soluble and usually has a high molecular weight. The tannins test on black pomegranate extract also showed 
positive results. Tannins are phenolic compounds that are water-soluble and typically have high molecular weight. Tanin has a toxic effect on other organisms because it can bind to proteins so that the mixture can have toxic effects and bioactivities such as antimicrobial (Alfarabi \& Widyadhari, 2018).

Alkaloid test results show negative results. Based on the literature, pomegranate skin contains an alkaloid, pelletriene, but the phytochemical screening results of pomegranate peel extract do not contain alkaloids. This is due to the small alkaloid content, which will be difficult to detect with the reagents used (Sopyan lyan, Rosa Apriana, 2017).

\section{Toxicity Test}

The results of the toxicity test using Artemia salina shrimp larvae on an ethanol extract of black pomegranate peel (Granati Fructus Cortex) shown in table 5. The number of larvae in each vial used in this study was 10, with a total of 100 larvae from 2 replications. Total larval deaths were obtained by adding up dead larvae at each concentration, while the average mortality was obtained by dividing the total deaths at each level against the number of replications performed. Then calculate the percentage of mortality from the average mortality at each concentration.

Table 5. Toxicity Test Results for Black Pomegranate Peel Extract (Granati Fructus Cortex) using Artemia salina shrimp larvae

\begin{tabular}{|c|c|c|c|c|c|c|}
\hline \multirow[t]{2}{*}{ Replication } & \multirow{2}{*}{$\begin{array}{c}\text { Control } \\
0 \\
\text { ppm }\end{array}$} & \multicolumn{4}{|c|}{$\begin{array}{c}\text { Total Mortality of Larvae each } \\
\text { Concentration }\end{array}$} & \multirow{2}{*}{$\begin{array}{l}\text { Volume of } \\
\text { Final } \\
\text { Media (ml) }\end{array}$} \\
\hline & & $\begin{array}{r}100 \\
\mathrm{ppm}\end{array}$ & $\begin{array}{l}150 \\
\mathrm{ppm}\end{array}$ & $\begin{array}{l}200 \\
\mathrm{ppm}\end{array}$ & $\begin{array}{l}250 \\
\mathrm{ppm}\end{array}$ & \\
\hline 1 & 0 & 4 & 7 & 9 & 10 & 10 \\
\hline 2 & 0 & 5 & 8 & 9 & 10 & 10 \\
\hline Total Mortality & 0 & 9 & 15 & 18 & 20 & \\
\hline Average & & 4,5 & 7,5 & 9 & 10 & \\
\hline$\%$ & & 45 & 75 & 90 & 100 & \\
\hline
\end{tabular}

From this table, it can seem that the various concentrations of ethanol extract of black pomegranate peel (Granati Fructus Cortex) show different effects on the percentage of Artemia salina Leach larvae mortality. Pearson correlation test was conducted to determine the relationship between concentration and the rate of larval deaths. In the correlation matrix obtained a significant value $<0.01$ that is 0.001 and the correlation value is positive with a number close to 1 that is 0.991 , so it can interpret that there is a correlation between concentration of black pomegranate peel extract with percentage of Artemia salina Leach death, the higher level of black pomegranate peel extract, the increasing percentage of Artemia salina Leach larvae mortality.

The results of probit analysis between ethanol extract concentrations of black pomegranate peel (Granati Fructus Cortex) to the percentage of Artemia salina Leach larvae mortality obtained LC50 price of ethanol extract of black pomegranate peel (Granati Fructus Cortex) that was $114.090 \mu \mathrm{g} / \mathrm{ml}$. Ethanol extract of black pomegranate peel (Granati Fructus Cortex) is included in a very toxic category because it has an LC50 price of $0-250 \mu \mathrm{g} / \mathrm{ml}$. Based on previous research, 
if a plant extract is toxic according to LC50 estimates by the BSLT method, then the plant can be developed as an anticancer drug (Kramy Prayogi, Triawanti, 2017).

In the past decade, numerous studies on pomegranate constituents have published. The results suggest that pomegranate components have antioxidant, anticarcinogenic, and anti-inflammatory ingredients, which are active in the prevention and treatment of cancer and other chronic and infectious diseases (Sharma, McClees, \& Afaq, 2017).

The Use of the pomegranate juice, peel, and oil has been indicated that pomegranate has anticancer activities, including interference with tumor cell proliferation, cell cycle, invasion, and angiogenesis (Khwairakpam et al., 2018). Pomegranate possesses antioxidant, anti-inflammatory, anti-proliferative, antiangiogenic, anti-invasive, and anti-metastatic properties, and induces apoptosis (Ozbay \& Nahta, 2011). It also down-regulates various signaling pathways such as NF-KB, PI3K/AKT/mTOR, and Wnt, and down-regulates the expression of genes that are responsible in cancer development, such as anti-apoptotic genes, MMPs, VEGF, cmet, cyclins, Cdks, and pro-inflammatory cytokines (Jahromi, 2018).

Pomegranate Peel has ellagitannins, ellagic acid, gallic acid, hydroxybenzoic acids such as ellagic acid, gallagic acid, and ellagic acid glycosides. Punicalagin is the major bioactive component of pomegranate peel. Anthocyanidins mainly contained cyanidin, pelargonidin, and delphinidin14 and flavonoids such as kaempferol, luteolin, and quercetin (Seidi, Esfahlan, Abasi, \& Abbasi, 2016).

Ozbay et al. (2011) reported that delphinidin presents growth inhibitory activity in breast cancer cells of different molecular subtypes but elevates potential drug antagonism when used in combination with existing targeted therapies in HER2overexpressing breast cancer. Therefore, the inclusion of pomegranate products such as black pomegranate peel extract (Granati Fructus Cortex) in diet would assist in a healthy life protected from cancer and also act as an effective chemotherapeutic with no toxic side effects.

\section{CONCLUSION}

Black pomegranate peel extract (Granati Fructus Cortex) contains active compounds, including flavonoids, saponins, and tannins. Black pomegranate peel extract (Granati Fructus Cortex) has an acute toxic potential against Artemia salina Leach larvae, which is indicated by LC50 values $<1000 \mu \mathrm{g} / \mathrm{ml}$. LC50 value of black pomegranate peel extract (Granati Fructus Cortex) is $114,090 \mu \mathrm{g} / \mathrm{ml}$, thus proving the existence of anticancer activity according to the Brine Shrimp Lethality Test (BSLT) method.

\section{ACKNOWLEDGMENT}

The author, thanks the Institute of Health Sciences Bhakti Wiyata Kediri for facilitating this research and thanks to the patients who were willing to contribute to this research. The suggestion for further research is that it is needed to isolate the active compound, which is toxic from black pomegranate peel (Granati Fructus Cortex), and cytotoxicity tests are required to be conducted both in vitro and in vivo from black pomegranate skin (Granati Fructus Cortex).

\section{REFERENCE}

Abnaz, Zahra Dzakirah, \& Jutti Levita. (2018). Buah Mengkudu (Morinda citrifolia L.) dan Biji Jinten Hitam (Nigella sativa L.) dan Teori Uji Toksisitas. Farmaka, 16, 213-221. 
Alfarabi, M., \& Widyadhari, G. (2018). Uji Toksisitas dan Identifikasi Fitokimia Ekstrak Buah Dan Batang Rimbang (Solanum torvum Swartz). Al-Kauniyah: Jurnal Biologi, 11(2), 109-115. https://doi.org/10.15408/kauniyah.v11i2.6360

Filha Ferraz, Lombardi, Guzzo, \& Guimarães, S. (2012). Brine shrimp (Artemia salina Leach) bioassay of extracts from Lychnophoriopsis candelabrum and different Lychnophora species. Revista Brasileira de Plantas Medicinais, 14(2), 358-361. https://doi.org/10.1590/S1516-05722012000200016

Fitri, R., Oktiarni, D., \& Arso, D. D. (2018). Eksplorasi Pengetahuan Obat Tradisional dalam Prespektif Hukum Kekayaan Intelektual di Bengkulu. Mimbar Hukum -

Fakultas Hukum Universitas Gadjah Mada, 30(2), 304.

https://doi.org/10.22146/jmh.31021

Jahromi, S. B. (2018). Punica granaturn (Pomegranate) activity in health promotion and cancer prevention. Oncology Reviews, 12(1), 1-7. https://doi.org/10.4081/oncol.2018.345

Khotimah, K. (2016). Skrining Fitokimia Dan Indentifikasi Metabolit Sekunder Senyawa Karpain Pada Ekstrak Metanol Daun Carica pubescens Lenne \& K. Koch Dengan LC /MS ( Liquid Chromatograph-tanden Mass Spectrometry. Skripsi. Universitas Islam Maulana Malik Ibrahim Malang. Retrieved from http://etheses.uin-malang.ac.id/3263/1/11620071.pdf

Khwairakpam, A. D., Bordoloi, D., Thakur, K. K., Monisha, J., Arfuso, F., Sethi, G., ... Kunnumakkara, A. B. (2018). Possible use of Punica granatum (Pomegranate) in cancer therapy. Pharmacological Research, 133, 53-64. https://doi.org/10.1016/j.phrs.2018.04.021

Kramy Prayogi, Triawanti, A. W. (2017). Uji Sitotoksik Ekstrak Etanol Caun Tumbuhan Jinjit (Desmodium Heterocarpon) terhadap Larva Artemia Salina Leach dengan Metode Brine Shrimp Lethality Test (BSLT). Jurnal Kedokteran Universitas Palangka Raya, 2.

Makiyah, A., \& Tresnayanti, S. (2017). Uji Toksisitas Akut yang Diukur dengan Penentuan LD50 Ekstrak Etanol Umbi lles-iles (Amorphophallus variabilis BI.) pada Tikus Putih Strain Wistar. Majalah Kedokteran Bandung, 49(3), 145-155. https://doi.org/10.15395/mkb.v49n3.1130

Muthmainnah, B. (2017). Uji Skrining Fitokimia Senyawa Metabolit Sekunder dari Ekstrak Etanol Buah Delima (Punica Granatum L.) dengan Metode Uji Warna. Media Farmasi, XIII(2), 23-28.

Ozbay, T., \& Nahta, R. (2011). Delphinidin inhibits HER2 and Erk1/2 signaling and suppresses growth of HER2-overexpressing and triple negative breast cancer cell lines. Breast Cancer: Basic and Clinical Research, 5(1), 143-154. https://doi.org/10.4137/BCBCR.S7156

Permana, A. H. C., Husni, A., \& Budhiyanti, S. A. (2016). Antioxidant Activity and Toxicity of Seagrass Cymodocea sp. Extracts. Jurnal Teknologi Pertanian, 17(1), 37-46. https://doi.org/10.21776/ub.jtp.2016.017.01.5

Putri, E. H. (2016). Uji Toksisitas Akut Ekstrak Etanol Daun Bidara terhadap Gambaran Morfologi dan Histologi Hati Mencit. Universitas Islam Negeri

Alauddin Makassar. Retrieved from https://www.bertelsmannstiftung.de/fileadmin/files/BSt/Publikationen/GrauePublikationen/MT_Globalizati on_Report_2018.pdf

Rakhmawati, M., Qadriyati, I., \& Wijayanti, L. (2011). The effect of red pomegranate (Punica ganatum) peel extract on leukocyte number and type in rats exposed with mobile phone electromagnetic radiation. Biofarmasi Journal of Natural Product Biochemistry, 9(2), 55-61. https://doi.org/10.13057/biofar/f090205 
Rampe, M. J., \& Toumbuku, J. L. (2015). Pengujian Fitokimia dan Toksisitas Ekstrak Etanol Jantung Pisang Kepok ( Musa paradisiaca LINN .) dengan Metode Brine Shrimp Lethality Test ( BSLT ) Phytochemistry and Toxicity Test of Ethanol Extract from Male, IV(2), 136-147.

Rizka, H. O., \& Saptarini, N. M. (2018). Pemanfaatan Kulit Buah Rambutan (Nephelim lappaceum Linn) Sebagai Sediaan Fungsional. Farmaka, 16, 78-83.

Roihatul, M. (2014). Antikanker Ekstrak Etanolik Tanaman Widuri. Malang: UIN Maliki Press.

Sangi, M. S., Momuat, L. I., \& Kumaunang, M. (2012). Uji Toksisitas Dan Skrining Fitokimia Tepung Gabah Pelepah Aren (Arenga pinnata). Jurnal Ilmiah Sains, 12(2), 127. https://doi.org/10.35799/jis.12.2.2012.716

Seidi, K., Esfahlan, R. J., Abasi, M., \& Abbasi, M. M. (2016). Anti tumoral properties of Punica granatum (Pomegranate) seed extract in different human cancer cells. Asian Pacific Journal of Cancer Prevention, 17(3), 1119-1122. https://doi.org/10.7314/APJCP.2016.17.3.1119

Setiawati, R. M. (2014). Pengaruh Variasi Komposisi Tanaman Delima ( Punica granatum Linn ) Terhadap Sifat Fisis Membran Komposit Untuk Menangkap Radikal Bebas Asap Rokok. Universias Islam Negeri Maulana Malik Ibrahim Malang.

Sharma, P., McClees, S. F., \& Afaq, F. (2017). Pomegranate for prevention and treatment of cancer: An update. Molecules, 22(1), 1-18. https://doi.org/10.3390/molecules22010177

Simaremartye, E. S. (2014). Skrining Fitokimia Ekstrak Etanol Daun Gatal (Laportea decumana (Roxb.) Wedd). Pharmacy, 11(01), 98-107.

Sopyan lyan, Rosa Apriana, D. G. (2017). Formulasi Sediaan Losio dari Ekstrak Kulit Buah Delima sebagai Tabir Surya. Farmaka, 14.

Syam, A. K. (2016). Uji Toksisitas Akut Ekstrak Etanol Daun Kayu Hitam terhadap Mencit (Mus Musculus). Universitas Islam Negeri Alauddin Makassar. https://doi.org/https://doi.org/10.3929/ethz-b-000238666

Yanuartono, Purnamaningsih, H., Nururrozi, A., \& Indarjulianto, S. (2017). Saponin: Dampak terhadap Ternak (Ulasan). Jurnal Peternakan Sriwijaya, 6(2), 79-90. https://doi.org/10.33230/jps.6.2.2017.5083 